\title{
Freud e Eliade: um debate sobre o fenômeno religioso
}

\author{
Antônio Vidal Nunes* \\ Rodrigo Danúbio Queiroz**
}

\section{Resumo}

O pensamento do filósofo romeno Mircea Eliade (1907-1986) situa-se em uma sociedade marcada por um Zeitgeist secularizado e, portanto, vazio de sentido religioso. Dentro dessas perspectivas imanentistas, encontra-se a interpretação de Sigmund Freud (1856-1939), que afirma ser a religião uma ilusão, uma neurose psíquica que precisa ser tratada para o amadurecimento da Humanidade. Freud, considerado por Eliade como o representante principal desse Zeitgeist, promoveu a dessacralização do espírito humano e a crise do teísmo. Ao discordar dessa posição, o pensador romeno elaborou uma teoria antirreducionista que apresentou um horizonte diferente da religião e do fenômeno religioso na vida do homem. Com base nessas afirmações, a presente pesquisa pretende apresentar a abordagem freudiana do fenômeno religioso e, em seguida, a crítica eliadiana ao criador da psicanálise.

Palavras-chave: Sagrado. Mircea Eliade. Freud. Fenômeno religioso.

\section{Freud and Eliade: a debate on the religious phenomenon.}

\section{Abstract}

The thought of the Romanian philosopher Mircea Eliade (1907-1986) is located in a society marked by a secularized Zeitgeist and therefore devoid of religious meaning. Within these immanent perspective, is the interpretation of Sigmund Freud (18561939), who claims to be a religion an illusion, a psychological neurosis that needs to be addressed for the maturation of humanity. Freud, considered by Eliade as the main representative of this Zeitgeist, promoted the desecration of the human spirit and the theism of the crisis. To disagree with that position, the romanian thinker produced an

* Professor associado da Universidade Federal do Espírito Santo. Possui graduação em pela Pontifícia Universidade Católica de Campinas (1981), mestrado em Educação pela Universidade Estadual de Campinas (1989) e doutorado em Educação pela Universidade de São Paulo (2001). Pós-Doutorado em Filosofia-UFRJ (2004). Atua na área de filosofia no Brasil, América Latina, e Filosofia da religião. E-mail: avidaln@uol.com.br

** Licenciado, bacharel e mestre em Filosofia pela Universidade Federal do Espírito Santo (UFES).rdanubioq@yahoo.com.br 
antireductionist theory that showed a different horizon of religion and the religious phenomenon in man's life. Based on these statements, the present study intends to present the freudian approach to the religious phenomenon and then the critical eliadiana the creator of psychoanalysis.

Keywords: Sacred. Mircea Eliade. Freud. Religious phenomenon.

\section{Freud y Eliade: un debate sobre el fenómeno religioso.}

\section{Resumen}

El pensamiento de la filósofa rumana Mircea Eliade (1907-1986) está situado en una sociedad marcada por un Zeitgeist secularizado y, por lo tanto, carece de significado religioso. Dentro de estas perspectivas inmanentistas, existe la interpretación de Sigmund Freud (1856-1939), quien afirma que la religión es una ilusión, una neurosis psíquica que necesita ser tratada para la madurez de la Humanidad. Freud, considerado por Eliade como el principal representante de este Zeitgeist, promovió la profanación del espíritu humano y la crisis del teísmo. En desacuerdo con esta posición, el pensador rumano desarrolló una teoría antirreduccionista que presentaba un horizonte diferente de religión y fenómeno religioso en la vida del hombre. Sobre la base de estas afirmaciones, la presente investigación tiene la intención de presentar el enfoque freudiano del fenómeno religioso y, más tarde, la crítica eliadiana al creador del psicoanálisis.

Palabras-clave: Sagrado. Mircea Eliade. Freud. Fenómeno religioso

No início do século XX, o pai da psicanálise, Sigmund Freud ${ }^{1}$ (18561939) dedicou parte de suas pesquisas à natureza da religião. Desenvolveu uma teoria a respeito da dimensão religiosa na vida do homem moderno e qual seria a necessidade de se manter a existência da religião em um período no qual a razão se apresentava como único critério válido para conduzir a Humanidade ao desenvolvimento científico. Suas reflexões sobre a religião são marcadas pelo cientificismo de sua época. Freud representa a modernidade e sua nova Weltanschanung ${ }^{2}$ como uma tentativa de eliminar a ideia da transcendência e voltar-se à imanência do homem, além de reduzir a religião a um produto dispensável ${ }^{3}$. Dessa forma, colocou em dúvida a consciência religiosa transcendente e elaborou uma nova consciência vazia

1 O filósofo e teólogo inglês John Hick (1922-2012) compara Freud, em importância de contribuição científica, a Galileu, Darwin e Einstein. Cf. HICK, 1970, p. 52.

2 Para Freud a Weltanschauung (visão de mundo) representa “[...] uma construção intelectual que soluciona todos os problemas de nossa existência, uniformemente, com base em uma hipótese superior dominante, a qual, por conseguinte, não deixa nenhuma pergunta sem resposta e na qual tudo o que possa nos interessar encontra seu lugar fixo" (FREUD, 1976a, p. 193).

3 Outros pensadores que também defenderam essa teoria foram Feuerbach (1804-1872), Nietzsche (1844-1900), Marx (1818-1883) e Sartre (1905-1980). Cf. ZILLES, p. 37, 2008. 
de sentido religioso, isto é, uma consciência secular. Com a corrente positivista de sua época, Freud defendeu a ideia de que, mediante o desenvolvimento do saber científico, o apego à religiosidade iria desaparecer.

Em $O$ futuro de uma ilusão, Freud elaborou uma abordagem da psicologia profunda ao interpretar culturalmente a origem da religião primitiva e o fenômeno religioso na consciência humana. Para ele, a religião é uma ilusão de um protótipo infantil da Humanidade: assim como uma criança busca a proteção e o cuidado na presença do pai, da mesma forma, os homens, impotentes perante os fenômenos terríveis da natureza como terremotos, enchentes, vendavais ou deficiências físicas e mentais, procuram, na imagem de um deus paternal e poderoso, a proteção. Nessa relação também ocorre uma interação entre o pai severo e amoroso com o filho. Freud afirmou que esse processo não se resume apenas a um protótipo infantil, mas também a um processo filogenético ${ }^{4}$.

O desamparo do homem, porém, permanece e, junto com ele, seu anseio pelo pai e pelos deuses. Estes mantêm sua tríplice missão: exorcizar os terrores da natureza, reconciliar os homens com a crueldade do Destino, particularmente a que é demonstrada na morte, e compensá-los pelos sofrimentos e privações que uma vida civilizada em comum lhes impôs (FREUD, 2006a, p. 26).

O deus humanizado, resultado da neurose psíquica humana, gera dogmas, conflitos e consequências psicológicas e sociológicas negativas para a Humanidade. O complexo paterno desenvolvido pelo homem religioso não passa de uma grande ilusão advinda dos desejos, dos delírios psíquicos gerados pela motivação de acreditar. Freud, ao afirmar que a religião é uma ilusão, não quis dizer necessariamente que ela fosse falsa, mas que ela existe somente para satisfazer os desejos e as neuroses ${ }^{5}$ dos que creem $^{6}$. Assim, a religião não seria

4 "Freud designa por 'filogenia' o processo evolutivo da Humanidade desde as suas origens. Formula a hipótese de que o desenvolvimento individual (a ontogenia) retoma da filogenia as suas principais fases, reproduzindo no indivíduo os acontecimentos traumáticos dessa história da Humanidade e desempenhando um papel estruturador nesse desenvolvimento; assim se explicaria a universalidade das fantasias originárias, do Édipo e, mais globalmente, de um esquema geral de desenvolvimento e funcionamento do psiquismo humano" (MIJOLLA, 2005, p. 723).

5 “Os psicanalistas classificam como 'neuroses' os transtornos psíquicos sem substrato anatômico detectável e cuja sintomatologia está ligada ao conflito intrapsíquico entre ideias fantasmáticas inconscientes, associadas ao complexo de Édipo e às defesas que elas suscitam" (Ibid., p. 1243).

6 "As neuroses não podem ser consideradas coisas sem importância, e a teoria psicanalítica 
uma delusão, embora seja improvável demonstrar a verificação de sua verdade. ${ }^{7}$

Freud prosseguiu em sua crítica à religião ao confrontar a tradição de seus ensinamentos. Duvidou dos fundamentos da tradição religiosa e afirmou que não passavam de relíquias neuróticas das antigas aspirações de fuga da finitude e dos poderes da natureza, fortalecidos na própria realização dos desejos. Ao ligar essas ideias a uma inteligência superior e assim almejar a uma vida mais tolerável (mesmo com um caminho difícil de trilhar), o homem religioso ordena tudo para algo melhor e transforma o mundo em um espaço protegido para viver. Essa "fuga da realidade" é um obstáculo ao desenvolvimento da Humanidade. Além disso, fundamenta a tradição cultural em princípios não verificáveis racionalmente, conforme o mestre da suspeita ${ }^{8}$ diz:

Tentemos aplicar o mesmo teste aos ensinamentos da religião. Quando indagamos em que se funda sua reivindicação a ser acreditada, deparamo-nos com três respostas, que se harmonizam de modo excepcionalmente mau umas com as outras. Em primeiro lugar, os ensinamentos merecem ser acreditados porque já o eram por nossos primitivos antepassados; em segundo, possuímos provas que nos foram transmitidas desde esses mesmos tempos primevos; em terceiro, é totalmente proibido levantar a questão de sua autenticidade. Em épocas anteriores, uma tal presunção era punida com os mais severos castigos, e ainda hoje a sociedade olha com desconfiança para qualquer tentativa de levantar novamente a questão (FREUD, 2006a, p. 35).

O sentimento religioso que Freud chamou de "sentimento profundamente religioso", serve como fundamento para alcançar uma experiência interior que dá acesso à "verdade". O sentimento se caracteriza pela "[...] admissão de insignificância ou impotência do homem diante do universo" (2006a, p. 41). Freud defendeu que esse sentimento não se encontrava em todos os homens, mas somente o dom da razão. Por isso, aqueles que assumiam essa postura compreensiva da realidade eram chamados de irreligiosos, e os

tem como sua própria origem a tentativa de compreender e curar as neuroses. De acordo com os freudianos, exatamente as mesmas forças estão em ação no comportamento normal e no anormal, porém, neste último, estão exaltadas e seus efeitos são mais perceptíveis" (HEIDBREDER, 1975, p. 342).

Cf. PALMER, 2001, p. 52.

8 A expressão "mestres da suspeita” foi cunhada pelo filósofo francês Paul Ricoeur (1913-2005) em Da interpretação. Ensaio sobre Freud (1965) para designar Marx, Nietzsche e Freud. Segundo Ricoeur, foram eles que suspeitaram das ilusões da consciência. Para Eliade, esses pensadores abordaram a crise da modernidade a partir de um horizonte provinciano e ocidental. 
que afirmavam ainda existir esse sentimento religioso e que o homem ainda se encontrava ligado à religião não passavam de fingidores, já que há muito tempo nos apartamos dela. "Na antropologia freudiana, não há lugar para uma relação de transcendência, que coloque em destaque a categoria do espírito como constitutiva do ser humano" (ROCHA, 1995, p. 451).

$\mathrm{Na}$ psicologia profunda, o sentimento religioso não passa de um problema psiquico. O homem sempre deseja a maior felicidade, “[...] mas entre seu desejo e a realidade há enorme distância. $\mathrm{O}$ infinito, contudo não passa de um produto do desejo e da fantasia do espírito humano, pois é apenas uma ideia, ou seja, uma ilusão" (ZILLES, 1991, p. 138). Freud se esforçou para explicar psicanaliticamente a ideia de que os homens receberam exteriormente uma indicação de como ser no mundo através de um sentimento imediato. Para ele, esse sentimento se originava no próprio ego, ainda que os indivíduos atribuíssem a uma experiência com o mundo externo9. Em O mal-estar na civilização, Freud denominou esse sentimento como "oceânico", e reconheceu a possibilidade dele existir em muitas pessoas e se caracterizar como uma origem primitiva do ego ${ }^{10}$.

Talvez devêssemos contentar-nos em afirmar que o que se passou na vida mental pode ser preservado, não sendo, necessariamente, destruído. É sempre possível que, mesmo na mente, algo do que é antigo seja apagado ou absorvido - quer no curso normal das coisas, quer como exceção - a tal ponto, que não possa ser restaurado nem revivescido por meio algum, ou que a preservação em geral dependa de certas condições favoráveis. É possível, mas nada sabemos a esse respeito. Podemos apenas prender-nos ao fato de ser antes regra, e não exceção, o passado achar-se preservado na vida mental (2006b, p. 80, grifo do autor).

9 Cf. FREUD, 2006b, p. 75.

10 "A vida psíquica dos seres humanos consiste em duas partes principais, o consciente e o inconsciente. O consciente é pequeno e relativamente insignificante. O que uma pessoa sabe sobre seus próprios motivos e conduta dá apenas um aspecto superficial e fragmentário de sua personalidade total. Por baixo do ego consciente está o vasto e poderoso inconsciente, fonte das grandes forças ocultas que constituem a verdadeira força impulsora das ações humanas. Entre o consciente e o inconsciente está o pré-consciente, que se funde gradualmente com ambos, mas que se parece mais com o consciente do que com o inconsciente em conteúdo e caráter e é acessível à consciência sem resistência emocional. O pré-consciente não formado pelo material que foi fortemente rejeitado e recalcado; em consequência, os seus conteúdos podem ser evocados pelos processos comuns de associação. A censura localiza-se geralmente no pré-consciente" (HEIDBREDER, 1975, p. 336). 
Entretanto, ele questionou a afirmação desse sentimento ser considerado a fonte da necessidade religiosa. Freud insistiu em defender sua tese que afirma que tal sentimento não passa de uma necessidade infantil da busca da proteção do pai. A origem da atitude religiosa é, na verdade, um sentimento do desamparo infantil. O sentimento oceânico, que defende a "unidade com o universo" é, na realidade, uma "[...] maneira de rejeitar o perigo que o ego reconhece a ameaçá-lo a partir do mundo externo" (FREUD, 2006b, p. 81).

Assim, nesse processo, o homem religioso, em sua tentativa de proteger o ego, encara a realidade como inimiga e uma fonte de sofrimento da qual não consegue viver. Por isso, para encontrar a felicidade, rompe todo tipo de relação. Freud citou como exemplo o eremita que rejeita o mundo e tenta construir outro espaço capaz de eliminar todos os seus aspectos insuportáveis adequando-se, indubitavelmente, aos seus desejos, em uma desesperada busca de fugir da realidade. Freud chamou de religião a essa tentativa de obter a felicidade somada à proteção da realidade que ocorre com grande número de pessoas como delírios de massa:

A religião restringe esse jogo de escolha e adaptação, desde que impõe igualmente a todos o seu próprio caminho para a aquisição da felicidade e da proteção contra o sofrimento. Sua técnica consiste em depreciar o valor da vida e deformar o quadro do mundo real de maneira delirante - maneira que pressupõe uma intimidação da inteligência. A esse preço, por fixá-las à força num estado de infantilismo psicológico e por arrastá-las a um delírio de massa, a religião consegue poupar a muitas pessoas uma neurose individual. Dificilmente, porém, algo mais. Existem, como dissemos, muitos caminhos que podem levar à felicidade passível de ser atingida pelos homens, mas nenhum que o faça com toda segurança. Mesmo a religião não consegue manter sua promessa. Se, finalmente, o crente se vê obrigado a falar dos "desígnios inescrutáveis" de Deus, está admitindo que tudo que lhe sobrou, como último consolo e fonte de prazer possíveis em seu sofrimento, foi uma submissão incondicional. E, se está preparado para isso, provavelmente poderia ter-se poupado o détour que efetuou (2006b, p. 92, grifo do autor).

O mal-estar na civilização ocorre pelo sentimento de culpa que se origina a partir de duas fontes: o medo da autoridade e o medo do Superego. O primeiro se funda na renúncia das satisfações instintivas ${ }^{11}$; o segundo exige

11 "A civilização tem de utilizar esforços supremos a fim de estabelecer limites para os instintos agressivos do homem e manter suas manifestações sob controle por formações 
a punição quando se tenta ou se pensa praticar atos libidinosos e agressivos. O homem religioso trata de modo severo a consciência e a obriga a renunciar aos instintos ${ }^{12}$. O sentimento de culpa é, portanto, resultado do medo de perder o amor e de perder a proteção divinizada da autoridade paterna. "A culpa é também um legado histórico, um fenômeno fundamental de nossa vida emocional adquirido pela raça humana como uma herança psíquica transmitida de geração a geração" (PALMER, 2001, p. 59).

Para que o elo não se rompa e o destino possa ser encarado como vontade divina, é necessário a renúncia ao instinto, aos desejos e o estabelecimento do sentimento de culpa e da punição. "Freud reitera sua concepção de que a civilização ao impor essas restrições à vida erótica, leva ao recalque, à frustração, ao ressentimento e à neurose" (Ibid., p. 57). No entanto, os homens encontram na religião uma forma de aliviar seus desejos proibidos, conforme nos mostra a psicóloga norte-americana Edna Heidbreder (1890-1985):

$\mathrm{E}$ as mesmas forças subterrâneas que agem nos indivíduos, também atuam na sociedade como um todo. De mil maneiras, a energia sexual é sublimada dirigida para canais aprovados pela sociedade. O mito, as cerimônias religiosas, os tabus tribais, as instituições sociais - todos eles, através do simbolismo ou algum outro disfarce, revelam a satisfação de desejos proibidos. As práticas de que se servem, embora muito convencionais devido ao uso e a repetição, têm suas raízes no inconsciente e estão carregadas de emoção. Toda a contextura da civilização está marcada pelo padrão freudiano - com conflito, repressão, interposição de resistência e caminhos indiretos para a satisfação (1975, p. 344).

Em Totem e Tabu, Freud defendeu a tese da gênese da religião se encontrar na relação do filho com o pai. Com isso, estabeleceu essa relação ambivalente com a teoria do complexo de Édipo. “[...] o complexo de Édipo

psíquicas reativas. Daí, portanto, o emprego de métodos destinados a incitar as pessoas a identificações e relacionamentos amorosos inibidos em sua finalidade, daí a restrição à vida sexual e daí, também, o mandamento ideal de amar ao próximo como a si mesmo, mandamento que é realmente justificado pelo fato de nada mais ir tão fortemente contra a natureza original do homem" (FREUD, 2006b, p. 117).

12 "Enquanto tudo corre bem com um homem, a sua consciência é lenitiva e permite que o ego faça todo tipo de coisas; entretanto, quando o infortúnio lhe sobrevém, ele busca sua alma, reconhece sua pecaminosidade, eleva as exigências de sua consciência, impõe-se abstinência e se castiga com penitências. Povos inteiros se comportaram dessa maneira, e ainda se comportam. Isso, contudo, é facilmente explicado pelo estágio infantil original da consciência, o qual, como vemos, não é abandonado após a introjeção no superego, persistindo lado a lado e por trás dele" (Ibid., p. 130). 
torna-se a repetição pessoal (e ontogenética) ${ }^{13}$ de algo que se acha embutido no inconsciente, isto é, a experiência universal (e filogenética) do assassinato do pai" (PALMER, 2001, p. 48). O complexo de Édipo, juntamente com o complexo de culpa como estrutura psíquica, se equivale à religião, pois está ligado ao sentimento religioso do totem e do tabu. Os totens simbolizam os complexos de crenças e pensamentos que influenciam os estímulos dos indivíduos e sua estrutura psíquica, e o tabu estabelece uma afetividade em relação ao objeto, isto é, uma relação de zelo e carinho capaz de criar, no homem, comportamentos externos expressos nos ritos.

Além disso, com base na hipótese de Charles Darwin (18091882) ${ }^{14}$ sobre o estado social primitivo da Humanidade, que afirma que o homem também viveu em pequenas hordas e, em seu interior, ocorreram sentimentos de ciúmes do macho mais velho (o pai) que, por ser o mais forte, proibia a promiscuidade sexual, Freud alegou que essa proibição foi quebrada pelo assassinato do pai pelos filhos. Por causa disso, surge uma marca permanente em todos os humanos: o complexo de Édipo. A esse respeito Jonh Hick (1922-2012) afirma:

A associação da religião com o complexo de Édipo, que é renovado em cada indivíduo (pois Freud acreditava que o complexo de Édipo era universal), foi estabelecida para explicar a misteriosa autoridade de Deus sobre o espírito humano e os poderosos sentimentos de culpa que tornam os homens submissos a tal fantasia. Assim, a religião é uma volta ao reprimido (1970, p. 54).

O recalque com a morte do pai e o desejo da mãe que ocorre no homem primevo se expressa na dor e no arrependimento no íntimo da estrutura psíquica e se manifesta na necessidade religiosa, no sentimento de culpa do homem religioso e na carência de prestar culto ao pai assassinado para reatar a relação afetiva e garantir a proteção.

13 Chama-se "ontogenia" (ou "ontogênese") a teoria do desenvolvimento e da organização
do indivíduo que leva em consideração sua origem e suas condições de produção. Freud
fundamentou essa teoria a partir dos estudos do médico e biólogo Ernst Haeckel (1834-
1919) que a enunciou nos seguintes termos: "A ontogenia resume a filogenia". De acordo
com essa lei, Haeckel e outros pensadores evolucionistas do século XIX afirmavam que, no
homem, o desenvolvimento do feto até ao estádio último (ontogenia) apresentava uma breve
recapitulação da história inteira da espécie (filogenia). Cf. MIJOLLA, 2005, p. 1316-1317.
Naturalista inglês, autor da A Origem das Espécies impressa em 1859, foi o responsável pela
ideia de evolução das espécies a partir de um anscestral comum por meio da seleção natural. 
Freud então afirmou que essas motivações da experiência religiosa eram, na verdade, motivações psíquicas originadas no sentimento do patricídio e transmitidas milenarmente. "Ao concluir, então esta investigação excepcionalmente condensada, gostaria de insistir em que o resultado dela mostra que os começos da religião, da moral, da sociedade e da arte convergem para o complexo de Édipo" (FREUD, 1976b, p. 185). Portanto, é o sentimento de culpa que se estabelece nas proibições ou nos tabus do totemismo que originou a religião. O centro dessa neurose, desse sentimento de culpabilidade é o complexo de Édipo. ${ }^{15}$

Embora Freud reconhecesse que a religião prestou grande contribuição à civilização ao controlar, mesmo que parcialmente, os instintos antissociais e, de certa forma, o sentimento religioso, permitiu que o homem se protegesse dos desastres naturais, do destino e de sua finitude, enfim, das hostilidades humanas e encontrou, nesse sentimento, uma fonte de referência para sua vida. Apesar de a religião dominar a sociedade, ela não conseguiu trazer felicidade.

Se houvesse conseguido tornar feliz a maioria da Humanidade, confortá-la, reconciliá-la com a vida, e transformá-la em veículo de civilização, ninguém sonharia em alterar as condições existentes. Mas, em vez disso, o que vemos? Vemos que um número estarrecedoramente grande de pessoas se mostram insatisfeitas e infelizes com a civilização, sentindo-a como um jugo do qual gostariam de se libertar; e que essas pessoas fazem tudo que se acha em seu poder para alterar a civilização, ou então vão tão longe em sua hostilidade contra ela, que nada têm a ver com a civilização ou com uma restrição do instinto. Nesse ponto, será objetado contra nós que esse estado de coisas se deve ao próprio fato de a religião ter perdido parte de sua influência sobre as massas humanas, exatamente por causa do deplorável efeito dos progressos da ciência (FREUD, 2006a, p. 46).

Como adepto do cientificismo, Freud defendeu que a religião deveria passar pelo tribunal da razão. ${ }^{16}$ Com isso, a religião não mais atenderia os

15 "Em particular, o fenômeno religioso é vinculado às dificuldades da existência e pela necessidade de proteção. Essa proteção objetiva-se na figura paterna, com todas as vivências ambivalentes que se produzem em relação a tal figura. Assim, as expressões rituais se tornam elementos de tranquilização e de propiciação, que se comportam segundo a dinâmica dos sintomas neuróticos de natureza obsessiva. É claro, pois, que Freud, avançando nesta linha, dissolve o fenômeno religioso para reduzi-lo às necessidades que tal fenômeno satisfaz no homem a para evidenciar os seus mecanismos psíquicos, através dos quais o fenômeno mesmo se realiza" (RIZZACASA, 1998, p. 552).

16 "Freud se baseia na existência de uma oposição radical entre a ciência natural e a religião, sendo a causa primordial do declínio da religião sua incapacidade de submeter-se a uma metodologia científica” (PALMER, 2001, p. 103). 
apelos e as expectativas da Humanidade e, por conseguinte, seria evidente sua derrocada. A religião é então, na perspectiva freudiana, o motivo cultural que obstrui o desenvolvimento da Humanidade, pois, como já mencionamos, consiste em uma fuga da realidade. Representa para a civilização uma neurose, ilusão, uma doença do espírito que precisa ser tratada.

A religião consiste em uma neurose infantil que só encontrará sua cura no momento em que for superada pela maturidade. Logo, é preciso substituíla por uma fonte capaz de levar-nos ao conhecimento da realidade fora de nós mesmos. A superação para a maturidade se encontra na realização da ciência. Freud disse que os homens esclarecidos devem buscar no deus logos ${ }^{17}$ as resposta de seus anseios. ${ }^{18}$ A respeito disso, ele afirmou:

É possível que a educação libertada do ônus das doutrinas religiosas não cause grande mudança na natureza psicológica do homem. O nosso deus

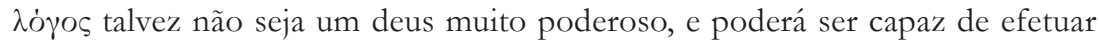
apenas uma pequena parte do que seus predecessores prometeram. Se tivermos de reconhecer isso, aceitá-lo-emos com resignação. Não será por causa disso que perderemos nosso interesse no mundo e na vida, pois dispomos de um apoio seguro, que falta a você. Acreditamos ser possível ao trabalho científico conseguir certo conhecimento da realidade do mundo, conhecimento através do qual podemos aumentar nosso poder e de acordo com o qual podemos organizar nossa vida. Se essa crença for uma ilusão, então nos encontraremos na mesma posição que você. Mas a ciência, através de seus numerosos e importantes sucessos, já nos deu provas de não ser uma ilusão (2006a, p. 62).

Mesmo reconhecendo que a maioria dos homens são menos guiados pelo intelecto do que por suas paixões e desejos, Freud acreditava que, caso educados cientificamente ${ }^{19}$ para perceber como a religião verdadeiramente é - uma ilusão -, poderia haver o progresso da civilização. A religião, uma neurose obsessiva universal, poderá ser finalmente superada quando o homem aprender a enfrentar o mundo confiando não mais em suas ilusões, mas no

17 Freud defende uma Weltanschanung científica, na qual se for necessário a existência de um deus, que esse seja o deus logos.

18 "Nesse processo, não há interrupção; quanto maior é o número de homens a quem os tesouros do conhecimento se tornam acessíveis, mais difundido é o afastamento da crença religiosa, a princípio somente de seus ornamentos obsoletos e objetáveis, mas, depois, também de seus postulados fundamentais" (FREUD, 2006a, p. 47).

19 "A educação para realidade de Freud é um postulado da razão humana, da capacidade das pessoas de pensar por si mesmas, livres do ônus do ensinamento religioso" (PALMER, 2001, p. 104). 
conhecimento científico. ${ }^{20} \mathrm{O}$ deus logos ajudará a libertar a Humanidade do complexo de Édipo e, consequentemente, fará com que a religião desapareça.

Em contraposição, Mircea Eliade (1907-1986), no decorrer de suas pesquisas, criticou as reflexões de Freud sobre a religião. ${ }^{21}$ Afirmou que o psicanalista analisou o homem somente pelo horizonte sentimental e psíquico, sem abordar a dimensão do mundo e da singular realidade existencial. Essa dimensão não está restrita à libido: o homem não é só desejo. Não se pode reduzir o homem como um ser que é somente determinado pelo prazer. ${ }^{22}$ Face a essa postura desmistificadora das abordagens científicas, Eliade afirmou ser uma tarefa fácil reduzir as formas arcaicas de compreensão aos seus elementos sociais, econômicos e políticos. $\mathrm{Na}$ verdade, trata-se de uma má interpretação dos significados religiosos. ${ }^{23}$

A linguagem brutal de Freud e de seus discípulos mais ortodoxos irritou muitas vezes os leitores de bom senso. Na realidade, essa brutalidade de linguagem é o resultado de um mal-entendido: não era a sexualidade em si que irritava, mas sim a ideologia fundada por Freud sobre a "sexualidade pura". Fascinado por sua missão - ele se acreditava o Grande Desperto, quando não passava do Último Positivista, [...] (ELIADE, 1991, p. 10).

Para o filósofo romeno, os símbolos, as imagens e as narrações mitológicas que servem de base para a psicologia profunda ao abordar o inconsciente humano, não são criações neuróticas da psique. Pelo contrário,

20 "Freud dá a parte da confiança ocidental na rąão ao destacar a infra-estrutura pulsional que subjaz nas auto-afirmações do eu, limitação do cogito desde o âmbito do inconsciente e a importância da configuração social da individualidade humana" (ESTRADA, 2003, p. 220, grifo nosso).

21 " [...] Eliade parece ver em Freud um personagem de transição ainda vinculado ao século XIX do ponto de vista metodológico, em sua atitude positivista, em seus preconceitos sobre a origem e a evolução das religiões, em seu reducionismo que o impulsiona a fazer uma interpretação não-religiosa e excessivamente elemental da imensa complexidade do simbolismo religioso" (ALLEN, 1985, p. 48). "[...] Eliade parece ver en Freud a un personaje de transición, vinculado todavía al siglo XIX en su metodología, su actitud positivista, sus prejuicios sobre el origen y la evolución de las religiones, su negativa postura ante el fenómeno religioso y en un reduccionismo que lo impulsa a hacer una interpretación no religiosa y excesivamente elemental de la inmensa complejidad del simbolismo religioso".

22 A metodologia de Eliade esclarece pontos que se relacionam com o anti-reducionismo e a irredutibilidade do sagrado: fatos religiosos devem ser interpretados em seu próprio plano de referência e tendo em conta a irredutibilidade do fenômeno religioso (Cf. Ibid., p. 218).

23 Cf. ELIADE, 1987, p. 101. 
são formas de responder a uma necessidade de revelar as mais secretas modalidades do ser que fazem parte da Humanidade anterior à História. ${ }^{24}$ Portanto, Freud se equivoca ao tratar essas representações em termos concretos, vazios de sentido. Mesmo que haja um esforço de decifrar esses códigos, ele não se esgota em sua interpretação. Ademais, ele tem uma postura etnocêntrica. Eliade não aceitou a universalidade do complexo de Édipo proposta pelo psicanalista.

O homem religioso se vale dos símbolos para captar a realidade mais profunda das coisas. Existe, nesses símbolos, um movimento dialético de desvelar e de cobrir que não poderia ser expresso por conceitos. Desse modo, "traduzir uma Imagem na sua terminologia concreta, reduzindo-a a um único dos seus planos referenciais, é pior que mutilá-la, é aniquilá-la, anulá-la como instrumento de conhecimento" (ELIADE, 1991, p. 12). Por isso, a atração que o filho sente pela mãe na teoria do complexo de Édipo é, para Eliade, limitada, pois são compreendidas em sua concretude, tal como ela é, não enquanto imagens. ${ }^{25}$ Assim, o desejo de possuir a mãe não quer dizer nada mais do que isso.

[...] Freud não podia se dar conta de que a sexualidade nunca foi "pura"; de que ela foi sempre e em toda a parte uma função polivalente, cuja valência primeira e talvez suprema era sua função cosmológica; de que traduzir uma situação psíquica em termos sexuais não é de forma alguma humilhá-la, pois exceto para o mundo moderno, a sexualidade foi sempre e em toda parte uma hierofania, e o ato sexual, um ato integral (ELIADE, 1991, p. 10).

Embora a psicologia profunda possa ser utilizada para compreender melhor o modo de ser do homem arcaico, não são necessárias suas descobertas para comprovar a existência de uma religiosidade no subconsciente do homem moderno. Tampouco são necessárias a atualidade e a força das imagens e dos símbolos. Mesmo com a alteração espiritual

24 Cf. ELIADE, 1991, p. 8-9.

25 "Freud traduz, positivisticamente, a Imagem da Mãe, na relação triangular edipiana, em termos concretos, reduzindo-a à mãe hic et nunc. Mas, contesta Eliade, somente a Imagem da Mãe pode revelar sua realidade e suas funções a um só tempo cosmológicas, antropológicas e psicológicas. Não se trata de negar, naturalmente, que possam existir casos de desequilíbrio psíquico em que a Imagem da Mãe não é mais do que o desejo incestuoso do indivíduo por sua própria mãe. Nesses casos, a Imagem da Mãe vem fixada em um único plano de referência - o plano concreto - e, por conseguinte, mutilada em sua significação Universal, exemplar" (GUIMARÃES, 2000, p. 246). 
resultante da dessacralização incessante do homem, não se romperam as raízes da sua imaginação "[...] todo um refugo mitológico sobrevive nas zonas mal controladas" (1991, p. 14). Os símbolos representam uma "abertura" para o transcendente. Eliade contestou a teoria de Freud de querer afirmar a imanência da existência humana e negar, com isso, qualquer forma de transcendência.

Em suma, a maioria dos homens "sem religião" partilha ainda das pseudo religiões e mitologias degradadas. Isso, porém, não nos surpreende, pois, como vimos, o homem profano descende do homo religiosus e não pode anular sua própria história, quer dizer, os comportamentos de seus antepassados religiosos, que o constituíram tal como ele é hoje (ELIADE, 2008a, p.170, grifo do autor).

De acordo com a Psicanálise, o "primordial humano" é a primeira infância. A criança vive num tempo mítico paradisíaco. Os estudos de Freud elaboraram técnicas capazes de revelar as origens que causaram o fim da infância e se tornaram o referencial da existência adulta como constitutivos de seu ser. A religião, bem como a sociedade e a cultura, tiveram seu início com um assassinato primevo. ${ }^{26}$ A teoria do totem não foi bem aceita pela comunidade científica. Eliade afirmou que Freud não deu a atenção necessária a essas recordações (nostalgias) ao reduzi-las a fragmentos psíquicos sem significado. Além disso, considerou a obra freudiana um modismo cultural de sua época: ${ }^{27}$ "Freud não se perturbou nem um pouco com essas objeções e, dessa forma, esse 'romance gótico' desvairado, Totem e Tabu, tornou-se, desde então, um dos evangelhos menores de três gerações da elite cultural do Ocidente" (ELIADE, 1979b, p. 11).

26 Essa interpretação da religião por parte de Freud foi criticada e rejeitada pelos etnólogos contemporâneos, como W. H. Rivers (1864-1922), Franz Boas (1858-1942), A. L. Kroeber (1876-1960), B. Malinowski (1884-1942) e W. Schmidt (1868-1954). Cf. ELIADE, 1989b, p. 36.

27 "Em vão, a crítica etnológica supra-referida demonstrou o absurdo de um 'banquete totêmico' primordial e a inexistência do totemismo no início da religião e que ele não é universal, em vão o próprio Frazer já havia provado que apenas quatro das muitas centenas de tribos totêmicas conheciam um rito próximo da cerimônia de morte e banquete do 'deus-totem' (um rito que Freud acreditou ser o traço constante do totemismo) e que este rito não tem nada a ver com a origem do sacrifício, uma vez que o totemismo não ocorre nas culturas mais antigas, e, finalmente, em vão Schmidt mostrou que os povos pré-totêmicos desconheciam o canibalismo, que um parricídio entre eles seria uma total impossibilidade psicológica, sociológica e ética" (GUIMARÃES, 2000, p. 326-327). 
Os símbolos ou mitos que manifestam o sentimento de nostalgia não devem ser interpretados, na sua particularidade, como elementos privados do sujeito, conforme a psicanálise avaliou. O mito é um modelo para o mundo inteiro, como uma revelação de mistérios pelo homem enquanto um ser total. Eliade defendeu que quando isso não ocorre, por conta da interpretação reducionista da Psicanálise, o mito degrada-se e transforma-se em um conto ou numa lenda.

Embora seja possível reconhecer as funções dos símbolos e os resultados dos acontecimentos da mitologia sobre o plano da atividade inconsciente, não se deve confundir o reconhecimento com a redução. “E quando o psicólogo 'explica’ uma Figura ou um Evento mitológico, reduzindo-os a um processo do inconsciente, que o Históriador das religiões hesita em seguir, e talvez não seja o único" (ELIADE, 1989a, p. 10). Sobre essa irredutibilidade do sagrado, afirma Mircea Eliade:

A “aura religiosa” de certos conteúdos do inconsciente não surpreende o Históriador das religiões: ele sabe que a experiência religiosa enquadra o homem na sua totalidade e, por conseguinte, também afecta as zonas profundas do seu ser. Isto não quer dizer que se reduza a religião aos seus componentes irracionais mais simplesmente do que se reconhece a experiência religiosa tal como ela é: a experiência da existência total, que revela ao homem a sua modalidade de ser no Mundo (Ibid., p. 12).

Eliade não dissociou o mito da ordem natural, sensual ou cognitiva. O mito é informado pelo cosmos; "amarra" os seres humanos à natureza e à sua imaginação mítica. Por isso, não podem operar de nenhum outro modo a não ser por meio dos sentidos e do simbolismo do corpo. Para ele, é sobre a psique que a imaginação mítica é incitada. Portanto, o mito não é uma saída para uma psique aberrante ou neurótica, mas uma expressão natural e saudável do inconsciente.

A importância eliadiana das representações dos mitos confronta-se com a posição de Freud que, como já vimos, afirmou que o mito (como a religião) é uma doença da psique humana que precisa de uma cura racional ${ }^{28}$.

28 [...] acreditava encontrar em sua obra a última fase absoluta de dessacralização do monoteísmo e do profetismo do Antigo Testamento. A sua certeza de ter descoberto a única e global explicação da vida mental, do psiquismo e da criatividade humana, de ter forjado a chave mágica que permitiria decifrar todos os enigmas, desde os sonhos ou atos falhos até as origens da religião, a moral e a civilização [...] Freud pensava que seus descobrimentos iam mudar a Humanidade e assegurar sua salvação (ELIADE 1982, p. 231). 
Freud colocou a origem do mito em um parricídio primal, como expressões superficiais do insconciente na vida do religioso. Por isso não é confiável. Em contrapartida, Eliade contesta:

Conclui-se, talvez um tanto depressa de mais, que as criações do inconsciente são a "matéria-prima" da religião e de tudo o que ela engloba: símbolos, mitos, ritos, etc. [...] A homogeneidade entre as personagens e os acontecimentos de um mito e de um sonho não implica a sua identidade de raiz. Nunca se repetirá de mais este truísmo, porque a tentação é sempre a de explicar os universos espirituais pela redução a uma "origem" pré-espiritual (Ibid., p. 12).

Mesmo com as fortes críticas da psicologia profunda à religião como uma doença do inconsciente humano, Eliade reconheceu que a descoberta de Freud do inconsciente foi, de fato, uma grande contribuição para a Humanidade. ${ }^{29}$ Porém, "[...] é claro que há que distinguir a grande contribuição de Freud para o saber, isto é, a sua descoberta do inconsciente e da psicanálise, da ideologia freudiana, que é apenas mais uma entre as inúmeras ideologias positivistas" (Ibid., p. 68).

O filósofo romeno utilizou proficuamente a teoria do inconsciente para fundamentar algumas de suas próprias teorias. ${ }^{30} \mathrm{~A}$ permanência do homo religiosus na vida do homem moderno se encontra nas "[...] modalidades arcaicas da vida psíquica, 'fósseis vivos' enterrados nas trevas do inconsciente tornavam-se então acessíveis ao estudo graças às técnicas elaboradas pelos psicólogos do profundo" (ELIADE, 1999, p. 2).

29 "Seria possível equiparar a descoberta do inconsciente às descobertas marítimas da Renascença e às descobertas astronômicas decorrentes do telescópio. Pois cada uma dessas descobertas desvendava mundos de cuja existência nem sequer suspeitava" (ELIADE, 1999, p. 1-2).

30 "Servindo-nos dos mesmos recursos e métodos da psicanálise moderna, podemos desvendar alguns segredos trágicos do intelectual ocidental moderno: por exemplo, sua insatisfação profunda com relação às formas desgastadas do cristianismo histórico e seu desejo de livrar-se violentamente da fé de seus antepassados, acompanhado de um estranho sentimento de culpa, como se ele próprio tivesse matado um Deus, em quem ele não podia acreditar, mas cuja ausência tomou-se insuportável. Por essa razão, eu disse que a corrente cultural é imensamente significativa, não importando o seu valor objetivo: o sucesso de certas ideias ou ideologias nos revela a situação espiritual e existencial daqueles para quem essas ideias ou ideologias constituem um tipo de soteriologia” (Id., 1979a, p. 12). 
Dentre as teorias fundamentadas nas ideias de Freud ${ }^{31}$, pode-se citar que a pesquisa de Eliade utilizou a beatitude da origem e do começo do ser humano; e a hipótese que afirma que, pela recordação ou mediante um voltar atrás, é possível reviver certos incidentes traumáticos da primeira infância. ${ }^{32}$ Com isso, é possível compreender a mentalidade do homem arcaico e se debruçar nas pesquisas sobre seu modus vivendi, pois o inconsciente revela a estrutura cósmica desse ser.

Pode-se ir mais longe ainda e afirmar não somente que o inconsciente é "mitológico", mas também que alguns de seus conteúdos estão carregados de valores cósmicos; em outros termos, que eles refletem as modalidades, os processos e os destinos da vida e da matéria vivente. Pode-se mesmo dizer que o único contato real do homem moderno com a sacralidade cósmica é efetuado pelo inconsciente que se trate de seus sonhos e de sua vida imaginária, quer das criações que surgem do inconsciente [...] (ELIADE, 2007, p. 73, nota 1).

Eliade constatou, a partir das técnicas da psicologia profunda, uma semelhança camuflada do homem arcaico com as ações e os gestos do homem a-religioso. As técnicas modernas da Psicanálise mantêm o padrão iniciático do Descensus ad Inferos. Isso se revela na medida em que o paciente precisa regressar ao seu próprio inconsciente para combater seus "monstros", sair vitorioso e encontrar suas saúde e integridade psíquica. ${ }^{33}$

Embora Eliade tenha reconhecido a existência alimentada por pulsões do inconsciente no homem, também afirmou que este, puramente racional, não se encontra na realidade. Por isso, a tentativa de Freud em defender uma educação científica para realidade está fadada ao fracasso. Pois existem nos indivíduos estruturas mitológicas constitutivas do homem religioso ${ }^{34}$ : “[...] o

31 "Sob certos aspectos, seria possível comparar a situação do historiador das religiões á do psicólogo do profundo. Tanto um como outro são obrigados a não perder o contato com os dados factuais; seus procedimentos são empíricos; sua finalidade é compreender 'situações': individuais, no caso do psicólogo; históricas, no caso do historiador das religiões” (ELIADE, 1999, p. 216).

32 Cf. Id., 2007, p. 73.

33 Cf. ELIADE, 2008a, p. 169

34 "Além do mais, grande parte de sua existência é alimentada por pulsões que lhe chegam do mais profundo de seu ser, da zona que se chamou de inconsciente. Um homem exclusivamente racional é uma abstração; jamais o encontramos na realidade. Todo ser humano é constituído, ao mesmo tempo, por uma atividade consciente e por experiências irracionais. Ora, os conteúdos e as estruturas do inconsciente apresentam semelhanças surpreendentes com as imagens e figuras mitológicas" (Ibid., p. 170). 
mito continua até hoje uma espécie de existência ambígua nas profundezas do inconsciente humano [...], em seguida, parece que, em seu 'mundo', o homem arcaico sente mais em casa do que o homem moderno [...]" (CULIANU, 2008, p. 108). ${ }^{35}$ Mas isso não quer dizer que os mitos consistem em produtos do inconsciente, já que revelam algo que se manifestou como um modelo exemplar. Seria um erro, portanto, tentar compreender esse fenômeno apenas sob uma perspectiva científica.

[...] um fenômeno religioso somente se revelará como tal com a condição de ser apreendido dentro da sua própria modalidade, isto é, de ser estudado á escala religiosa. Querer delimitar este fenômeno pela fisiologia, pela psicologia, pela sociologia e pela ciência econômica, pela linguística e pela arte, etc... é traí-lo, é deixar escapar precisamente aquilo que nele existe de único e de irredutível, ou seja, seu caráter sagrado (ELIADE, 2008b, p. 1).

A antropologia eliadiana defende que o homem é dotado de transcendência, de uma existência aberta com ricos significados. O inconsciente apresenta, portanto, uma aura religiosa que, no decorrer do tempo, foi ocultada pela História e pelo pensamento científico. "Mas as 'mitologias' privadas do homem moderno - seus sonhos, devaneios, fantasias etc. - não conseguem alçar-se ao regime ontológico dos mitos, justamente porque não são vividas pelo homem total [...]" (ELIADE, 2008a, p. 171-172, grifo do autor). Resulta daí a crise existencial, que é religiosa, como já mencionamos, vivenciada pelo homem moderno.

Como visto, Eliade deu uma importância muito grande às zonas do inconsciente: "A atividade do inconsciente do homem moderno não cessa de lhe apresentar inúmeros símbolos, e cada um tem uma certa mensagem a transmitir, uma certa missão a desempenhar, tendo em vista assegurar o equilíbrio da psique ou restabelecê-lo" (ELIADE, 2008a, p. 172). Para que isso ocorra e "salve" o homem de sua situação individual, é preciso que ele fique "aberto" ao universal. Porém, a abertura só ocorre na medida em que

35 " [...] il mito continua una specie di esistenza equivoca nel profondo dell inconscio umano [...] allora effettivamente sembra che nel suo "mondo" uomo arcaico si sentisse più a casa di quanto uomo oderno non si senta nel suo".

36 "Todavia, os conteúdos e estruturas do inconsciente são o resultado das situações existenciais imemoriais, sobretudo das situações críticas, e é por essa razão que o inconsciente apresenta uma aura religiosa. Toda crise existencial põe de novo em questão, ao mesmo tempo, a realidade do Mundo e a presença do homem no Mundo [...]" (ELIADE, 2008a, p. 171). 
se torna um homem integral. Eliade defendeu que, somente nessa perspectiva, o inconsciente, encarado como religião ocultada na mente humana, pode ajudar o homem a enfrentar suas crises.

De certo ponto de vista, quase se poderia dizer que, entre os modernos que se proclamam a-religiosos, a religião e a mitologia estão "ocultas" nas trevas de seu inconsciente - o que significa também que as possibilidades de reintegrar uma experiência religiosa da vida jazem, nesses seres, muito profundamente neles próprios (ibid., p. 173).

Eliade utilizou a filogenia de Freud para afirmar que ela ainda se encontra na mentalidade do homem moderno, por ser sua raiz, de forma camuflada." "Acreditamos que seja da maior importância redescobrir toda uma mitologia, se não uma teologia, escondida na vida mais 'banal' de um homem moderno" (ELIADE, 1991, p. 15). Basta o homem reconhecer suas raízes religiosas e redescobrir os significados profundos dos símbolos e dos mitos degradados.

Que não nos digam que todo esse refugo não interessa mais ao homem moderno, que pertence a um "passado supersticioso", felizmente eliminado pelo século XIX; que só serve para os poetas, para as crianças, ou para as pessoas do metrô se saciarem de imagens e de nostalgias, mas que (por favor!) deixem as pessoas sérias continuarem a pensar, a "fazer história": uma tal separação entre o que é "sério na vida" e os "sonhos" não corresponde à realidade (Id., 1991, p. 15).

No Tratado de história das religiões, o romeno afirmou que a principal diferença do homem moderno em relação ao homem das culturas arcaicas reside na incapacidade do homem a-religioso de viver uma vida orgânica como um sacramento. ${ }^{38}$ Tanto a Psicanálise quanto o materialismo histórico estudaram e julgaram encontrar etnograficamente as bases do princípio religioso na sexualidade, no trabalho e na nutrição. Contudo, desprezaram o significado e sua função real nos povos arcaicos, pois, “[...] para o moderno não passam de atos fisiológicos, ao passo que para o homem das culturas arcaicas são sacramentos, cerimônias por cujo intermédio se comunica com a força que

\footnotetext{
37 Contudo, ele acrescenta o termo "onto", mas o altera para "ontofilogenética" e assim designa a descendência psicológica do homo religiosus no homem moderno. Cf. ELIADE, 2008b, p. 198.

38 Cf. Ibid., p. 36.
} 
representa a própria vida" (2008b, p. 36). Os rituais simbolizam a união com sagrado e permitem ao homem arcaico se aproximar da realidade a se inserir no ôntico, ao pertencer ao ser que o liberta do nada, do profano. Esse modo de vida é a Weltanschaunng do homem religioso. ${ }^{39}$

No escritos de Eliade percebemos que sua postura contrária à visão unilateral ocidental surgiu a partir de uma busca de um novo modo de explicar o homem para além do pensamento de Kant, de Hegel, de Nietzsche e de outros pensadores marcantes de sua época. Eliade foi crítico de Freud na medida em que suas teorias fragmentaram o homem aos seus condicionamentos fisiológicos e patológicos. Eliade reivindicou o caráter único e irredutível dos fenômenos religiosos, que só a partir do sagrado poderiam ser revelados. Dessa forma, o sagrado é a realidade absoluta. Ao criticar a ontologia arcaica, as correntes materialistas apresentaram propostas de pensar a realidade e o homem sem qualquer transcendência. O esquecimento do Ser resultou na crise existencial do homem. Logo, a crise humana é uma crise ontológica na medida em que se dá pela perda do sentido de ser.

\section{Referências}

ALLEN, Douglas. Mircea Eliade y el fenomeno religioso. Madrid: Ediciones Cristiandad, 1985. CULIANU, Ioan Petru. Mircea Eliade. Roma: Edizioni Settimo Sigillo, 2008.

ELIADE, Mircea. Fragmentos de un diario. Madri: Espasa-Calpes, 1979a.

Ocultismo, bruxaria e correntes culturais: ensaios em religiões comparadas. Belo Horizonte: Interlivros, 1979 b.

Memória I. 1907-1937. Las promesas del equinoccio. Madri: Taurus, 1982.

A provação do labirinto. Lisboa: Dom Quixote, 1987.

Mitos, Sonhos e Mistérios. Lisboa: Edições 70, 1989a.

Origens, História e sentido na religião. Lisboa: Edições 70, 1989b.

Imagens e Símbolos: ensaio sobre o simbolismo mágico-religioso. São Paulo: Martins Fontes, 1991.

Mefistófeles e o Andrógino: comportamentos religiosos e valores espirituais não-europeus. São Paulo: Martins Fontes. 1999.

Mito e realidade. São Paulo: Perspectiva, 2007.

39 Eliade denominou a Weltanschaunng religiosa (como elemento principal a dialética sagrado-profano) de "ontologia arcaica" como concepção da consciência religiosa. Cf. GUIMARÃES, 2000, p. 132. 
O sagrado e o profano: a essência das religiões. São Paulo: Martins Fontes, 2008a. . Tratado de História das religiões. São Paulo: Martins Fontes, 2008b.

ESTRADA, Juan Antonio. Deus nas tradições filósoficas - Vol. II Da morte de Deus à crise do sujeito. São Paulo: Paulus, 2003.

GUIMARÃES, André Eduardo. O Sagrado e a história: fenômeno religioso e valorização da história à luz do anti-historicismo de Mircea Eliade. Porto Alegre: EDIPUCRS, 2000.

HEIDBREDER, Edna. Psicologias do século XX. São Paulo: Editora Mestre Jou, 1975.

HICK, John. Filosofia da religião. Rio de Janeiro: Zahar Editores, 1970.

FREUD, Sigmund. Nova Conferência introdutórias sobre a psicanálise: Conferência XXXV, A questão de uma Weltanschanung. Edição Standard brasileira das obras psicológicas completas de S. Freud. Vol. XXII. Rio de Janeiro: Imago, 1976a.

. Totem e Tabu. Edição standard brasileira das obras psicológicas completas de S. Freud. Vol. XII Rio de Janeiro: Imago, 1976b.

O futuro de uma ilusão. Edição standard brasileira das obras psicológicas completas de S. Freud.Vol. XXI Rio de Janeiro: Imago, 2006a.

. O mal-estar na civilização. Edição standard brasileira das obras psicológicas completas de S. Freud.Vol. XXI Rio de Janeiro: Imago, 2006b.

MIJOLLA, Alain de (Dir.). Dicionário internacional da psicanálise: conceitos, noções, biografias, obras, eventos, instituições. Rio de Janeiro: Imago, 2005.

PALMER, Michael. Freud e Jung sobre a religião. São Paulo: Edições Loyola, 2001.

ROCHA, Zeferino. FREUD: Aproximações. 2º ed. Recife: Ed. Universitária da UFPE, 1995.

RIZZACASA, Aurelio. Psicanálise e experiência religiosa: panorama In: PENZO, Giorgio; GIBELLINI, Rosino (Orgs.). Deus na filosofia do século XX. São Paulo: Loyola 1998.

ZILLES, Urbano. A crítica da religião na modernidade. INTERAÇÕES - Cultura e Comunidade / v. 3 n. 4 / p. 37-54 / 2008. Disponível em: <http://periodicos.pucminas.br/ index.php/interacoes/article/view/6707/6134>. Acesso em: 18 out. 2014.

Filosofia da religião. São Paulo: Paulus, 1991.

Submetido em: 10-3-2020

Aceito em: 14-8-2020 